Annals of Warsaw University of Life Sciences - SGGW

Land Reclamation No 46 (1), 2014: 3-15

(Ann. Warsaw Univ. Life Sci. - SGGW, Land Reclam. 46 (1), 2014)

\title{
Thermal and snow conditions of winters and winter floods on example of Zagożdżonka River
}

\author{
AGNIESZKA HEJDUK ${ }^{1}$, LESZEK HEJDUK ${ }^{2}$ \\ Laboratory - Water Center ${ }^{1}$, Department of Hydraulic Engineering ${ }^{2}$ \\ Warsaw University of Life Sciences - SGGW
}

\begin{abstract}
Thermal and snow conditions of winters and winter floods on example of Zagożdżonka River. Thermal and snowy conditions in Zagożdżonka River catchment during hydrological years 2003-2013 and winter floods are presented in paper. The meteorological and hydrological data, such as maximum, minimum, mean diurnal air temperatures, daily snow cover depth, and water discharge, collected at Czarna station (WULS-SGGW) have been used. Meteorological conditions were analyzed using indexes proposed by Paczos. Temperate cold and extraordinarily low snowy winters has dominated in Zagożdżonka catchment in presented period of time. Winter floods as a result of snowmelt have been observed almost each year, except 2008 when winter was mild and extremely low snowy. The relation between winter severity index $\left(W O_{z}\right)$ and winter snowiness index $\left(W S_{n}\right)$ has been estimated, as well as the relation between winter snowiness index and maximum discharge $\left(Q_{\max }\right)$.
\end{abstract}

Key words: winter severity, winter snowiness, winter floods

\section{INTRODUCTION}

The climate warming has been registered in both, the global (Kundzewicz 2008, 2011) and local scale (Kożuchowski, Żmudzka 2001; Marsz, 2005; Kundzewicz, Kozyra 2011). Those works indicated a multidirectional changes of thermal conditions in the various months of the year for last 30 years. It is confirmed that the temperature of January, February and March has increased. It is also expected, that the spring runoff will be reduced, due to the increasing temperature and decreasing snow cover and precipitation (Piętka 2009).

Thermal and snowiness classification of winters is difficult, because the climate, weather and the winters in Poland diverse in a wide range. Published works relate to the thermal conditions (Piotrowicz 2002; Biniak-Pieróg et al. 2012; Grabowski et al. 2013) or snow cover (Chrzanowski 1988; Nowosad, Bartoszek 2007; Wojkowski 2009; Wojkowski, Partyka, 2009; Czarnecka 2011, 2012). The problem of both, thermal and snowy conditions of winters and in particular the occurrence of extremely cold and snowy or extremely mild and low snowy winters recently have been the subject of regional investigations carried out by Janasz (2000), Olba-Zięty, Grabowski (2007), Majewski et al. (2011). Studies in Poland scale have been carried out by Paczos $(1982,1985)$ and recently by Ziernicka-Wojtaszek (2013). Paczos (1982) have found the dependencies between winter severity and snowiness indexes. The other cited authors confirmed this relation, based on the collected data 
from different parts of Poland. However there are no much investigations, which describe the relation between winter conditions and floods caused by snowmelt on the lowland areas. Therefore the scope of this paper is an estimation of relation between chosen meteorological condition in a form of winter snowiness index and winter severity index, their relation and changeability during years as well as relation between those indexes and runoff. All analysis has been carried based on the data collection from small catchment in the middle part of Poland.

\section{MATERIAL AND METHODS}

\section{Study catchment}

The investigation was based on the data collected by the Department of Hydraulic Engineering, Warsaw University of Life Sciences - SGGW, from the 23.4 $\mathrm{km}^{2}$ lowland catchment of Zagożdżonka
River at the Czarna gauging station. Located in central Poland (Fig. 1) Zagożdżonka River is a left tributary of Vistula River. The catchment area, which contributes to direct runoff (without local depressions) to river system is 19.6 $\mathrm{km}^{2}$, upstream of Czarna gauge (shown as B in Fig. 1). Absolute relief is $26.5 \mathrm{~m}$ in this subcatchment. The mean slopes of main streams are from 2.5 to $3.5 \mathrm{~m}$ per $1000 \mathrm{~m}$ (Hejduk, Banasik 2010a).

Sandy soils (from almost pure to loamy sands), which covered $90 \%$ of watershed to Czarna gauging station are the main type of soils. In local depressions and river flood plains peaty soils may be found. Land use in the watershed upstream of Czarna gauge is dominated by arable land $-70 \%$ of total area; $20 \%$ of area is covered by forest, $9.4 \%$ is pastures and $0.6 \%$ is paved areas.

According to Banasik et al. (2013), the mean annual precipitation and run-

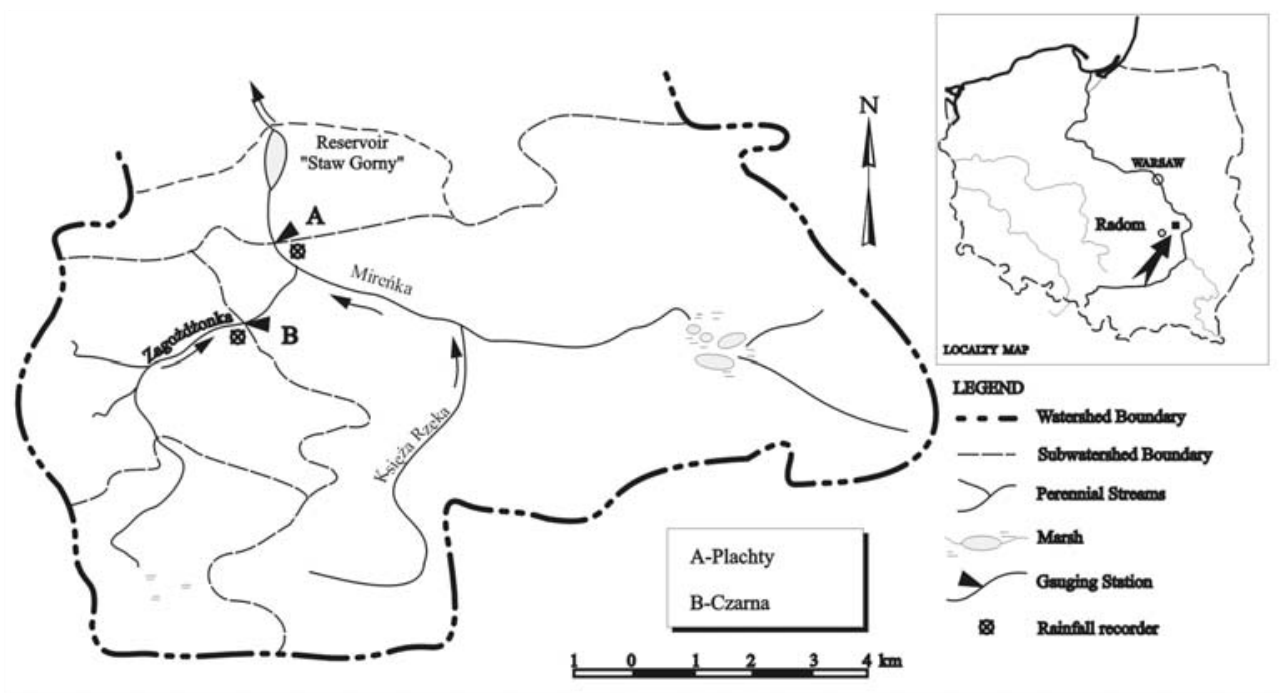

FIGURE 1. Locality map of the watershed 
off for Zagożdżonka catchment from the period 1963-2011 are estimated at $612 \mathrm{~mm}$ (range: $941 \mathrm{~mm}$ in $1974-$ $414 \mathrm{~mm}$ in 1991) and $107 \mathrm{~mm}$ respectively (range: $209 \mathrm{~mm}$ in $1980-52 \mathrm{~mm}$ in 1992). The month with the highest rainfall (average $81.8 \mathrm{~mm}$ ) is July, while the precipitation in January is the lowest in the year $(31.7 \mathrm{~mm})$. The month which is the most abundant in water is March, while the most dry is July (Banasik et al. 2013). Average precipitation in winter season for hydrological years 2003-2013 was $215 \mathrm{~mm}$, with range of $166-258 \mathrm{~mm}$. According to rainfall distribution in presented period of time, the driest one was April $(32.6 \mathrm{~mm})$. The rest of months of winter season had similar amount of precipitation.

Since hydrological year 2003 snow cover depth and water equivalent at Czarna is measured. The snow cover usually appears between 25-30 of November and disappears between 20-25 of March. The snowmelt period is usually $1-4$ days long (Hejduk 2009).

The average discharge of the years 1991-2010 for Zagożdżonka River till Czarna gauging station is $0.071 \mathrm{~m}^{3} / \mathrm{s}$ (Hejduk 2011a). Two-year-flood discharge $\left(W Q_{50 \%}\right)$ equals $1.04 \mathrm{~m}^{3} / \mathrm{s}$ (Hejduk, Banasik 2010a). The mean annual suspended sediment concentration (SSC) is low and has been estimated for $14 \mathrm{mg} / 1$ (Hejduk 2001; Hejduk et al. 2010), however for snowmelt floods it has been estimated for $19.5 \mathrm{mg} / \mathrm{l}$ (Hejduk, Banasik 2010a). Yearly total sediment yield from Czarna station is about $60 \mathrm{Mg}$ (Banasik 1983). Winter floods in Zagożdżonka River are in most cases snowmelt-rain- fall one. They can provide the biggest amount of suspended sediment during hydrological year.

\section{Measurements}

All calculations were based on the data collected at Czarna gauging station. Air temperature and water level were measured using an electronic equipment with 10 minutes time step (Hejduk et. al. 2010; Hejduk, Deelstra 2011). The discharge has been estimated based on hydraulic rating curve for sharp-crested weir (Hejduk, Banasik 2010b), which has been verified using hydrometric measurements, taken several times during hydrological year. Discharge and precipitation allowed to determine the hydrograph of winter flows and identify winter floods. The snow cover depth has been measured at least once a day at 7 a.m. using lowland type of Chomicz's weight snow-sampler (Janiszewski 1988; Hejduk 2009). In case of intensive snowfall the measurement were taken few times a day according to IMGW standards (Janiszewski 1988). The measurement allows to determine snow water equivalent too.

The daily hydrograph, observations of snow cover, temperature and precipitations allowed to determined snowmelt periods and floods. The data of air temperature and snow cover depth has been used to calculate winter severity and snowiness indexes.

\section{Calculations of winter severity index and snowiness index}

Within the meaning of meteorological season, the winter is usually describe as a period between December $1^{\text {st }}$ and 
February $28^{\text {th }}$ or $29^{\text {th }}$. In Poland March and beginning of April are very often characterized by the weather conditions typical for winter season, such as air temperature below $0^{\circ} \mathrm{C}$ and the snow cover. According to hydrological year (from November $1^{\text {st }}$ to October $31^{\text {st }}$ the next year) winter season is a period between November $1^{\text {st }}$ and April $30^{\text {th }}$. This is a time, when the meteorological conditions are typical for autumn, winter and early spring.

Paczos (1982) has analyzed the data set from several meteorological stations, which were representative for the different regions of Poland. He has calculated selected thermal and snow characteristics. Based on these analyses, as a winter period he has adopted the time from December $1^{\text {st }}$ till the end of March and proposed the method of calculation the winter severity and snowiness indexes. In this methodology winter severity index is determined based on temperature's characteristics of winter season and winter snowiness index is calculated based on snow cover depth.

Winter severity has been determined by using numerical index proposed by Paczos (1982), modified by Janasz (2000), computed from the following empirical formula:

$W O_{\mathrm{z}}=(1-0.25 \cdot t) \cdot 0.8325+0.0144 \cdot d_{z}+$ $+0.0087 \cdot d_{m}+0.0045 \cdot d_{b m}-0.0026 \cdot S_{t}$ where:

$W O_{z}$ - winter severity index, from 0 - the mildest winter, to 10 - the most severe winter $(-)$,

$t$ - average temperature of the winter season $\left({ }^{\circ} \mathrm{C}\right)$,

$d_{z}$ - the number of winter days, average daily temperature, $t_{a}<0^{\circ} \mathrm{C}$,

$d_{m}$ - the number of frosty days, $t_{\max }<0^{\circ} \mathrm{C}$, $d_{b m}$ - the number of very frosty days, $t_{\max }<-10^{\circ} \mathrm{C}$,

$S_{t}-$ the sum of average daily air temperature below $0^{\circ} \mathrm{C}$,

Winter snowiness index, has been calculated also from Paczos' formula:

$$
\begin{aligned}
W S_{n}= & 0.0409 \cdot d_{p s}+0.0246 \cdot d_{p s 20}+ \\
& +0.00007 \cdot S_{h}
\end{aligned}
$$

where:

$W S_{n}-$ winter snowiness index, from 0 to $10(-)$,

$d_{p s}$ - the number of days with snow cover depth above $1 \mathrm{~cm}$, $d_{p s 20}$ - the number of days with snow cover depth above $20 \mathrm{~cm}$,

$S_{h}$ - the sum of total depth of snow in the winter season $(\mathrm{cm})$.

According to Chrzanowski's (1988) classification, the snow cover depth between 20 and $40 \mathrm{~cm}$ is recognize as thick one. Based on calculated indexes of thermal and snowiness, Paczos (1982) has estimated ten types of thermal and snowy characteristics of winter (Table 1). 
TABLE 1. Types of winter severity and snowiness by Paczos (1982)

\begin{tabular}{|c|c|c|c|c|c|}
\hline \multicolumn{3}{|c|}{ Winter severity } & \multicolumn{2}{c|}{ Winter snowiness } \\
\hline Type & $W O_{z}$ & Thermal classification & Type & $W S_{n}$ & Snowiness classification \\
\hline I & $0.01-1.00$ & very mild & I & $0.01-1.00$ & extremely low snowy \\
\hline II & $1.01-2.00$ & mild & II & $1.01-2.00$ & extraordinary low snowy \\
\hline III & $2.01-3.00$ & temperate mild & III & $2.01-3.00$ & very low snowy \\
\hline IV & $3.01-4.00$ & temperate cold & IV & $3.01-4.00$ & temperate low snowy \\
\hline V & $4.01-5.00$ & cold & V & $4.01-5.00$ & low snowy \\
\hline VI & $5.01-6.00$ & temperate severe & VI & $5.01-6.00$ & temperate snowy \\
\hline VII & $6.01-7.00$ & severe & VII & $6.01-7.00$ & snowy \\
\hline VIII & $7.01-8.00$ & very severe & VIII & $7.01-8.00$ & very snowy \\
\hline IX & $8.01-9.00$ & extraordinary severe & IX & $8.01-9.00$ & extraordinary snowy \\
\hline X & $9.01-10.00$ & extremely severe & X & $9.01-10.00$ & extremely snowy \\
\hline
\end{tabular}

\section{RESULTS AND DISCUSSION}

\section{Thermal characteristic and snow cover of considered time period}

The average air temperature in the winter season (XI-IV) of hydrological years 2003-2013 at Czarna station (Table 2) ranged from 3.6 to $-1.2^{\circ} \mathrm{C}$ with a standard deviation of $1.2^{\circ} \mathrm{C}$. Warmest months are November and April with the monthly average air temperature of 4.3 and $8.4^{\circ} \mathrm{C}$ respectively. The coldest months are January and February with an average temperature of -2.9 and $-2.6^{\circ} \mathrm{C}$ respectively.

The winter season of 2007 was the warmest one with an average air temperature of $3.6^{\circ} \mathrm{C}$, while the coldest winter has been observed in hydrological year 2006 with an average air temperature of $-1.2^{\circ} \mathrm{C}$. The lowest air temperature $\left(-32{ }^{\circ} \mathrm{C}\right)$ at Czarna station in 2006 has been recorded on January $23^{\text {rd }}$ and $24^{\text {th }}$. The air temperatures below $0^{\circ} \mathrm{C}$ persisted throughout January and February and the most of March.

The snow cover has been observed in each year of 2003-2013 (Fig. 2). 11-years average total number of days with snow cover was 67 , which is close to average for this region of Poland. Chrzanowski (1988) has estimated the total number of days with snow cover equal to 70 for central part of Poland. There was the low number of days with snow cover above $20 \mathrm{~cm}$ observed (average 11 days) almost each year, except 2006 and 2010 (57 and 39 days respectively). The decreasing number of days with thick snow cover suggests changes in thermal regime of winters and confirms warming of this season. 
TABLE 2. The average air temperature, winter severity index $\left(W O_{z}\right)$ and snowiness index $\left(W S_{n}\right)$ at Czarna station during hydrological years 2003-2013

\begin{tabular}{|c|c|c|c|c|c|c|c|c|c|c|}
\hline \multirow{2}{*}{$\begin{array}{l}\text { Hydrologi- } \\
\text { cal year }\end{array}$} & \multicolumn{8}{|c|}{ Average air temperature $\left({ }^{\circ} \mathrm{C}\right)$} & \multirow{2}{*}{$\begin{array}{c}W O_{z} \\
(-)\end{array}$} & \multirow{2}{*}{$\begin{array}{l}W S_{n} \\
(-)\end{array}$} \\
\hline & $\mathrm{XI}$ & XII & $\mathrm{I}$ & II & III & IV & XI-IV & XII-III & & \\
\hline 2003 & 4.3 & -6.0 & -2.9 & -5.4 & 2.2 & 7.4 & -0.1 & -3.0 & 4.3 & 1.8 \\
\hline 2004 & 6.5 & 0.1 & -5.4 & -1.0 & 2.2 & 7.0 & 1.6 & -1.0 & 3.2 & 2.9 \\
\hline 2005 & 3.1 & 1.3 & -0.4 & -4.4 & -0.9 & 8.0 & 1.1 & -1.1 & 3.1 & 2.5 \\
\hline 2006 & 2.3 & -1.3 & -9.8 & -4.3 & -1.8 & 8.0 & -1.2 & -4.3 & 5.2 & 6.1 \\
\hline 2007 & 4.8 & 2.6 & 2.6 & -1.6 & 5.6 & 7.5 & 3.6 & 2.3 & 1.1 & 1.2 \\
\hline 2008 & 0.6 & -1.3 & 0.3 & 2.0 & 2.6 & 8.3 & 2.1 & 0.9 & 1.8 & 0.3 \\
\hline 2009 & 5.0 & 1.2 & -3.1 & -0.9 & 2.2 & 9.7 & 2.4 & -0.2 & 2.4 & 1.7 \\
\hline 2010 & 5.6 & -0.9 & -8.2 & -1.6 & 3.5 & 9.1 & 1.3 & -1.8 & 4.0 & 3.7 \\
\hline 2011 & 6.9 & -5.5 & -0.7 & -4.2 & 3.0 & 10.1 & 1.6 & -1.8 & 3.7 & 3.8 \\
\hline 2012 & 2.4 & 2.4 & -1.2 & -6.7 & 4.3 & 9.6 & 1.8 & -0.3 & 2.6 & 1.3 \\
\hline 2013 & 5.6 & -2.9 & -3.3 & -0.6 & -1.9 & 8.1 & 0.8 & -2.2 & 3.9 & 3.4 \\
\hline Average & 4.3 & -0.9 & -2.9 & -2.6 & 1.9 & 8.4 & 1.4 & -1.1 & 3.2 & 2.6 \\
\hline Maximum & 6.9 & 2.6 & 2.6 & 2.0 & 5.6 & 10.1 & 3.6 & 2.3 & 5.2 & 6.1 \\
\hline Minimum & 0.6 & -6.0 & -9.8 & -6.7 & -1.9 & 7.0 & -1.2 & -4.3 & 1.1 & 0.3 \\
\hline $\begin{array}{l}\text { Standard } \\
\text { deviation }\end{array}$ & 2.0 & 3.0 & 3.7 & 2.6 & 2.4 & 1.1 & 1.2 & 1.8 & 1.2 & 1.6 \\
\hline
\end{tabular}

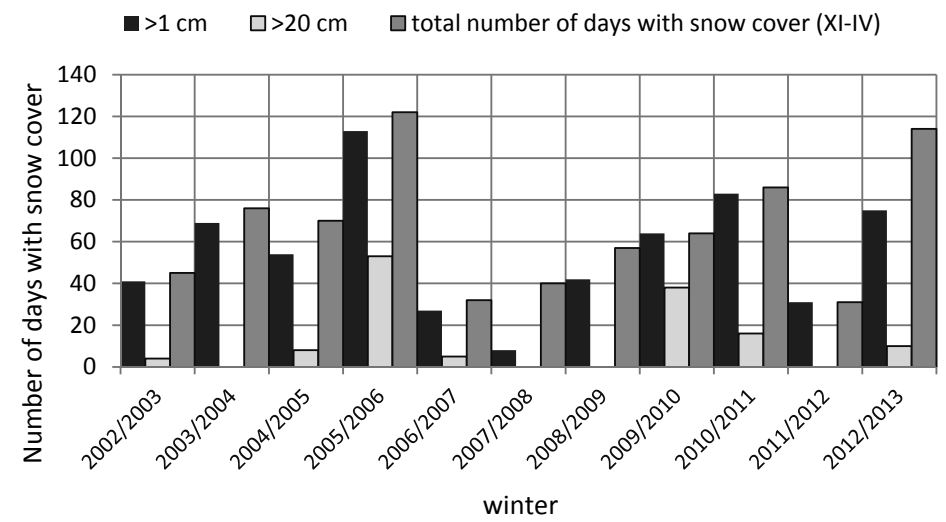

FIGURE 2. The number of days with snow cover

\section{Winter severity and snowiness}

Both, winter severity and snowiness indexes have been calculated for the period from December to March. The value of winter severity index $\left(W O_{z}\right)$ ranged from 5.2 to 1.1 with a standard deviation
1.2. In the analyzed period, four types of winter severity (Table 3 ) have been observed: mild winter occurred twice (II), as well as temperate mild winter (III). Four times temperate cold winter (IV) was observed. Once temperate severe 
TABLE 3. Thermal and snowiness classification of winters 2003-2013

\begin{tabular}{|c|c|c|c|c|}
\hline Winter & Type & Thermal classification & Type & Snowiness classification \\
\hline $2002 / 2003$ & V & cold & II & extraordinarily low snowy \\
\hline $2003 / 2004$ & IV & temperate cold & III & very low snowy \\
\hline $2004 / 2005$ & IV & temperate cold & III & very low snowy \\
\hline $2005 / 2006$ & VI & temperate severe & VII & snowy \\
\hline $2006 / 2007$ & II & mild & II & extraordinarily low snowy \\
\hline $2007 / 2008$ & II & mild & I & extremely low snowy \\
\hline $2008 / 2009$ & III & temperate mild & II & extraordinarily low snowy \\
\hline $2009 / 2010$ & IV & temperate mild & IV & temperate low snowy \\
\hline $2010 / 2011$ & IV & temperate cold & IV & temperate low snowy \\
\hline $2011 / 2012$ & III & temperate mild & II & extraordinarily low snowy \\
\hline $2012 / 2013$ & IV & temperate cold & IV & temperate low snowy \\
\hline Average & & temperate cold & & extraordinarily low snowy \\
\hline
\end{tabular}

winter (VI) occurred, and at the same time it was the most snowy winter (VII) in analyzed period of time. Because of short period of investigations, it is difficult to estimate the tendencies in winter severity. During first four years of research, cold, temperate cold and temperate severe winters occurred. Mild and temperate mild winters have been recorded five times during last seven years. After winter 2005/2006 there was no winter with thermal type higher then IV.

Winter snowiness index ranged from 6.1 to 0.3 with a standard deviation 1.6. In two of the four cases of temperate cold winter, the season was very low snowy (III), in two others temperate low snowy (IV). In 2007 and 2008 winters were mild but in 2007 extraordinarily low snowy (II) and in 2008 extremely low snowy (I). Winters of 2009 and 2012 were classified as temperate cold but also extraordinarily low snowy (II). Similar to winter serenity, after winter 2005/2006 there was no winter with snowiness type higher then IV

\section{Winter severity index and winter snowiness index relation}

There is a significant statistical correlation between winter severity index $W O_{z}$ and winter snowiness index $-W S_{n}$ (Fig. 3), with the correlation index $\mathrm{R}=$ $=0.83, \alpha=0.05$. Similar relation were observed by other researchers. Paczos (1982) received correlation coefficient between $W O_{z}$ and $W S_{n}$ equal to 0.88 for Poland, Majewski et al. (2011) for WULS-SGGW meteorological station received correlation coefficient equal to 0.79 , Olba-Zięty and Grabowski (2007) for Biebrza Valley equal to 0.71 . It means that along with the progressive warming, the number of days with snow cover will be reduced. The requirement 


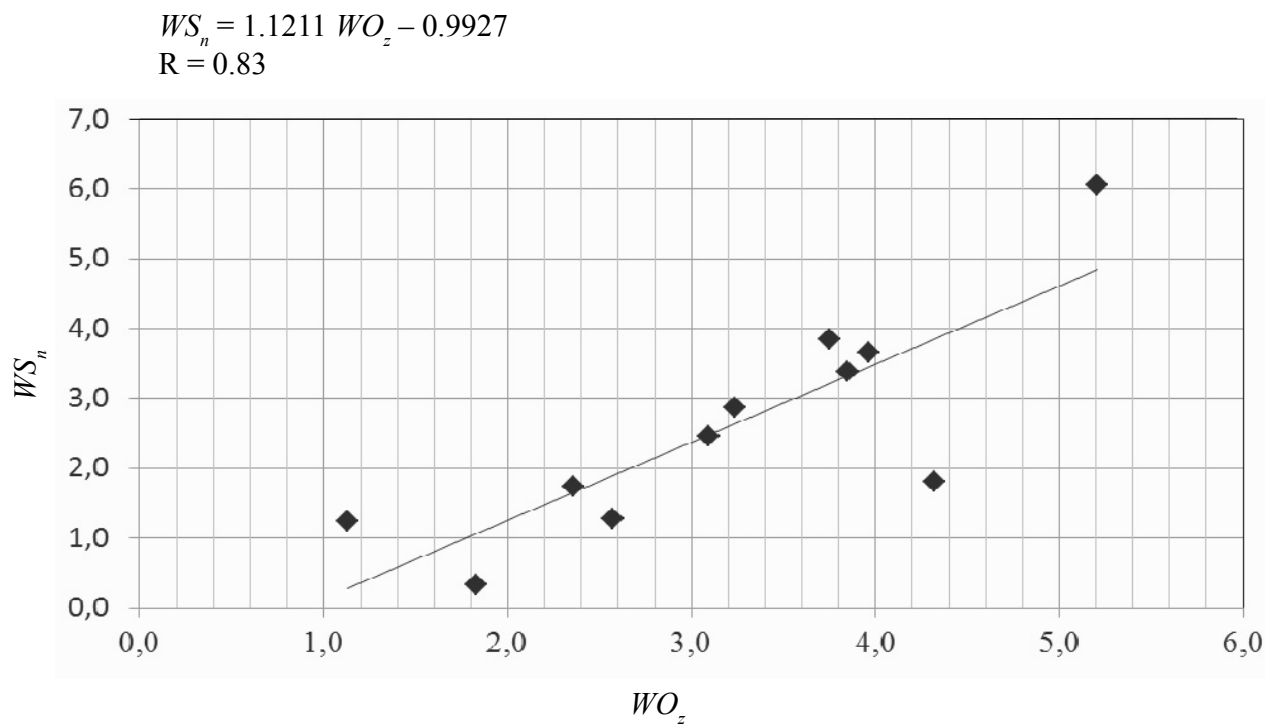

FIGURE 3. The relationship between snowiness index and thermal severity index in Zagożdżonka catchment in 2002/2003-2012/2013

for the snow cover formation is a moderate or heavy snowfall, which creates and strengthens the snow cover. Low air temperature is a factor in the formation and maintenance of snow cover. The snow cover will exist as long as air temperature will be respectively low. This explains the correlation between $W O_{z}$ and $W S_{n}$.

\section{Maximum water discharge and winter snowiness index relation}

During 2003-2013 hydrological years winter floods as a result of snowmelt have been observed almost each year. Table 4 shows basic characteristic of snowmelt floods during this period. The peak of winter floods of 2003, 2005, 2006, 2010, 2011 and 2013 at least once during the season was about two-year-flood or higher.
The biggest snowmelt flood was recorded in March 2005, when the winter was temperate cold and very low snowy. The flood was the result of rapid snowmelt with very small amount of rain. The maximum discharge of this event was $3.444 \mathrm{~m}^{3} / \mathrm{s}$, which was three times more than two-year-flood discharge. The volume of the flood $\left(V=316.3 \cdot 10^{3} \mathrm{~m}^{3}\right)$ was $14.6 \%$ of total runoff (total runoff of 2005 was equal to $2,172.4 \cdot 10^{3} \mathrm{~m}^{3}$ ). This flood transported $14.02 \mathrm{Mg}$ of sediment, which was $23.4 \%$ of total annual sediment yield. The second biggest snowmelt flood was observed in March 2006 with maximum discharge of $2.781 \mathrm{~m}^{3} / \mathrm{s}$ and the volume of $295.7 \cdot 10^{3} \mathrm{~m}^{3}$, which was $15.6 \%$ of total runoff (total runoff of 2006 was equal to $\left.1,892 \cdot 2 \cdot 10^{3} \mathrm{~m}^{3}\right)$. The mass of suspended sediment transported during this event was $10.43 \mathrm{Mg}(17.4 \%$ of total annual sediment yield). 
TABLE 4. General characteristic of collected snowmelt events of Zagożdżonka River at Czarna station

\begin{tabular}{|l|c|}
\hline Category & Range \\
\hline Maximum discharge, $Q_{\max }\left(\mathrm{m}^{3} / \mathrm{s}\right)$ & $0.144-3.444$ \\
\hline Average discharge, $Q_{a}\left(\mathrm{~m}^{3} / \mathrm{s}\right)$ & $0.090-1.268$ \\
\hline Volume of surface runoff, $V_{p}\left(10^{3} \mathrm{~m}^{3}\right)$ & $5.0-316.3$ \\
\hline Total supply in snowmelt period $(=$ melt + rainfall $), M P(\mathrm{~mm})$ & $10.0-69.3$ \\
\hline Effective supply, $M P_{\text {ef }}(\mathrm{mm})$ & $0.26-16.22$ \\
\hline Sediment yield, $M(\mathrm{Mg})$ & $0.08-14.02$ \\
\hline Average suspended sediment concentration, $S S C_{a}(\mathrm{mg} / \mathrm{l})$ & $10.7-25.0$ \\
\hline
\end{tabular}

During winter time water is stored in accumulating snow cover. Few days long periods of warming can happen during the whole winter season, and cause the slowly melt of snow. Depending on air temperature, the snow cover may melt slowly or rapidly, when the long-term warming is coming. The high amount of accumulating snow, which melts rapidly, can generate higher runoff then that which would have been caused by rainfall in the same time (Makku et al. 2007). This has happened in winter 2005. The air temperature has been continuously low since the end of January till the middle of March. The few-days-long period of warming in February was too short to melt the snow. Accumulated snow cover has melted rapidly in March during the warm period, generated the high runoff and transported the high amount of sediment.

In 2006 low temperatures have been recorded since the end of January till the end of March, with few short periods of maximum temperature above $0^{\circ} \mathrm{C}$. The warming period has come slowly. At first the snow cover has started to melt with no reaction from the catchment. Rapid increased of air temperature and rainfall in the same time caused the formation of flood.
In 2004, 2007, 2008, 2009 and 2012 the daily discharge of winter season was lower than $0.5 \mathrm{~m}^{3} / \mathrm{s}$. In 2008 , when the winter was mild and extremely low snowy, there was no reaction of the catchment on snowmelt. In fact there was no typical winter flood recorded as a consequence of snow thaw. The situation of 2012 was special too. Hydrological year 2012 was dry. November 2011 has been classified as extremely dry. The water storage in catchment at the beginning of winter season was small. The discharge of the whole winter season was low, even if it was higher than in summer half of the year. The winter was temperate cold and temperate low snowy. The temperature before snowmelt period was above $0^{\circ} \mathrm{C}$, the soil was unfrozen. The reaction of the catchment on snowmelt was observed twice, the maximum of the discharge of each event was about $0.2 \mathrm{~m}^{3} / \mathrm{s}$. Observed surface runoff was not high. In this case three parameters have been important: the water storage of catchment at the beginning of winter, thin snow cover (the amount of water accumulated in snow cover was low), and unfrozen soil (which has facilitated infiltration during snowmelt period). In February the streamflow drought 
was observed in winter for the first time since the beginning of research. The summary of the discharge of Czarna station in winter seasons of 2003-2013 is given in Table 5.

TABLE 5. The average, maximum and minimum discharge at Czarna station, based on daily data set

\begin{tabular}{|c|c|c|c|}
\hline \multirow{2}{*}{ Winter } & \multicolumn{3}{|c|}{ The discharge of winter season } \\
\cline { 2 - 4 } & $Q_{a}$ & $Q_{\max }$ & $Q_{\min }$ \\
\hline $2002 / 2003$ & 0.087 & 1.09 & 0.035 \\
\hline $2003 / 2004$ & 0.079 & 0.341 & 0.031 \\
\hline $2004 / 2005$ & 0.091 & 2.023 & 0.033 \\
\hline $2005 / 2006$ & 0.088 & 1.678 & 0.025 \\
\hline $2006 / 2007$ & 0.092 & 0.497 & 0.036 \\
\hline $2007 / 2008$ & 0.055 & 0.215 & 0.024 \\
\hline $2008 / 2009$ & 0.071 & 0.329 & 0.019 \\
\hline $2009 / 2010$ & 0.114 & 1.009 & 0.006 \\
\hline $2010 / 2011$ & 0.197 & 1.259 & 0.034 \\
\hline $2011 / 2012$ & 0.066 & 0.233 & 0.007 \\
\hline $2012 / 2013$ & 0.116 & 1.251 & 0.030 \\
\hline
\end{tabular}

The rapid snowmelt supplies the catchment and the water level increases. Low temperature has an impact on snow cover as well as snowmelt may have influence on the discharge. The relation between average and maximum discharge and snowiness index has been soughed. There was no significant correlation between average discharge and snowiness but a significant statistical correlation $(\mathrm{R}=0.66, \alpha=0.05)$ between the maximum water discharge and the snowiness conditions has been found (Fig. 4). This relation indicate that the maximum discharge during winter could be connected with snowiness - if snowiness is higher the discharge caused by flood after melting of snow will be higher. However, data series of snow cover measurements for Zagożdżonka River are 11 years and it is still short period of time. For example, the point representing the winter season of hy-

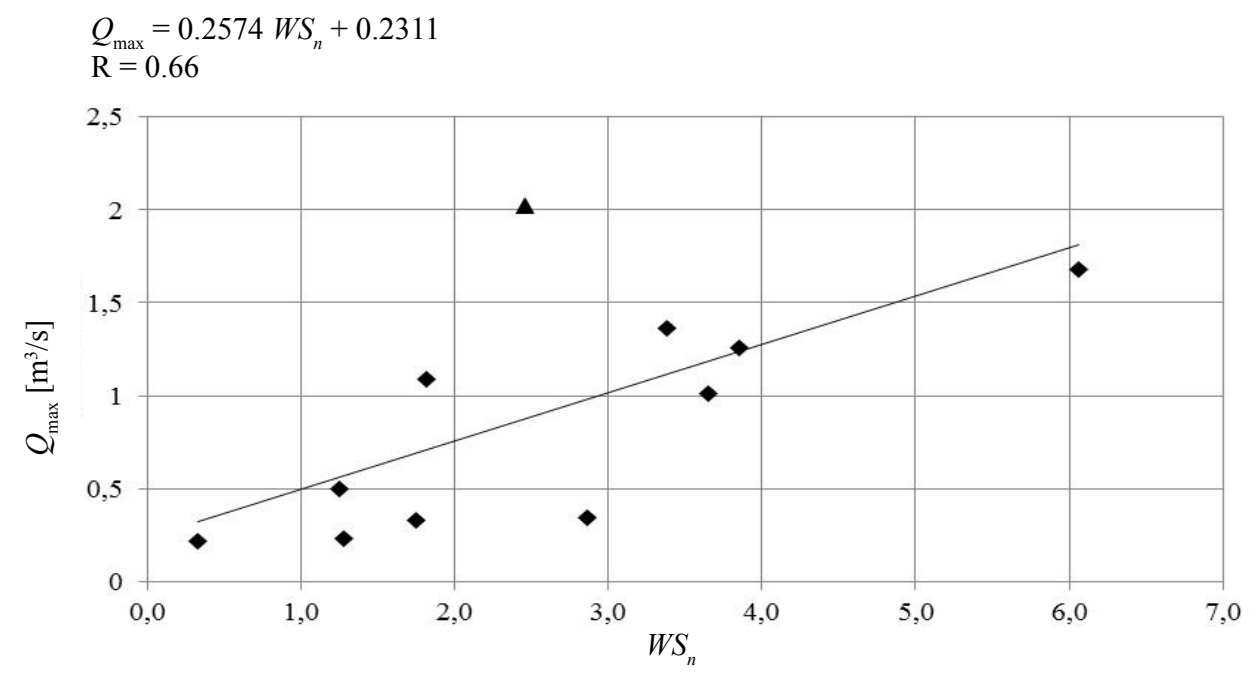

FIGURE 4. The relation between winter snowiness index $\left(W S_{n}\right)$ and maximum water discharge $\left(Q_{\max }\right)$ of winter season. $\boldsymbol{\Delta}$ represents $Q_{\max }$ of 2005 
drological year 2005 (marked as triangle in Fig. 4), stands out significantly from the remaining points. Taking into account that the winter flood recorded in March 2005 was on the top of extreme events in Zagożdżonka catchment, this situation was unusual, not typical even for winter season, when big floods happen. On the other hand, hydrological and meteorological processes in catchment scale are complicated and simple linear equation presented in this paper may not describe all snowmelt - runoff situations, so the research on the link between meteorological and hydrological parameters should be continued on longer data set.

\section{CONCLUSIONS}

1. According to the thermal and snowiness classification, temperate cold and extraordinarily low snowy winters has dominated in Zagożdżonka catchment during investigated period 2003-2013.

2. The most severe and snowy was winter 2005/2006. The most mild and in the same time extremely low snowy was winter 2007/2008.

3. The decreasing number of days with thick snow cover may suggests changes in thermal regime of winters.

4. There is a significant statistical relationship between winter snowiness index $-W S_{n}$ and winter severity index - WO $(\mathrm{R}=0.83, \alpha=0.05)$. Based on this relation, along with the progressive warming, the number of days with snow cover will be reduced.
5. During 2003-2013 hydrological years winter floods as a result of snowmelt have been observed almost each year, except 2008 when winter was mild and extremely low snowy.

6. There is statistical significant relation between maximum water discharge and snowiness conditions $(\mathrm{R}=0.66, \alpha=0.05)$. The relation indicates that if the snowiness is higher the maximum discharge should be higher too.

\section{Acknowledgments}

The investigation was carried on within the research project funded by National Science Center.

\section{REFERENCES}

BANASIK K. 1983: Rozmieszczenie użytków w zlewni jako czynnik minimalizujący natężenie transportu rumowiska $\mathrm{w}$ korycie rzecznym [Distribution of grassland in the catchment as limiting factor of sediment transport in river bed]. Unpublished Ph.D. thesis. Warsaw University of Life Sciences - SGGW.

BANASIK K., HEJDUK L., HEJDUK A., KAZNOWSKA E., BANASIK J., BYCZKOWSKI A. 2013: Wieloletnia zmienność odpływu z małej zlewni rzecznej w regionie Puszczy Kozienickiej [Long-term variability of runoff from a small catchment in the region of the Kozienice Forest]. Sylwan 157 (8): 578-586 [Engl. summ.].

BINIAK-PIERÓG M., KAJEWSKA-SZKUDLAREK J., ŻYROMSKI A., LAKATOS L. 2012: Tendencje maksymalnych wartości temperatury powietrza $\mathrm{w}$ półroczu zimowym we Wrocławiu-Swojcu [Long-term tendencies of maximum air temperature in the winter half-year in Wrocław-Swojec]. Woda - Środowisko - Obszary Wiejskie 12, 4 (40): 31-43 [Engl. summ.]. 
CHRZANOWSKI J. 1988: Pokrywa śnieżna w Polsce. Klasyfikacja jej grubości i regionalizacja [Snow cover in Poland. Thickness classification and regionalization]. Prace badawcze IMGW - Meteorologia, Warszawa.

CZARNECKA M. 2011: Zmienność terminów początku i końca pokrywy śnieżnej o różnym czasie zalegania i ich uwarunkowania cyrkulacyjne [Variability of the dates of the beginning and end of snow cover of different duration time and conditions of their circulation]. Prace i Studia Geograficzne 47: 109-118 [Engl. summ.].

CZARNECKA M. 2012: Częstość występowania i grubość pokrywy śnieżnej w Polsce. [Frequency of occurrence and depth of snow cover in Poland]. Acta Agrophysica 19 (3): 501-514 [Engl. summ.].

GRABOWSKI J., OLBA-ZIĘTY E., BANASZKIEWICZ B., POŻARSKA K. 2013: Charakterystyka termiczna okresu zimowego w dwóch mezoregionach Polski północno-wschodniej [Thermal characteristics of winter period in two mesoregions of north-eastern Poland]. Annales Universitatis Mariae Curie-Skłodowska, Lublin - Polonia LXVIII (2), SECTIO E: 33-41 [Engl. summ.].

HEJDUK A. 2009: Transport rumowiska unoszonego podczas wezbrań roztopowych w małej zlewni rolniczej [Suspended sediment transport during snowmelt flood events in small agricultural watershed]. Unpublished Ph.D. thesis. Warsaw University of Life Sciences - SGGW [Engl. summ.].

HEJDUK L. 2011: Badania transportu rumowiska i biogenów w skali zlewni [Studies of sediment transport and nutrients in a catchment scale]. Unpublished internal report of project COST 869 „Migrations Option for Nutrient Reduction in Surface Water and Groundwater". Warsaw University of Life Sciences - SGGW.

HEJDUK A., BANASIK K. 2010a: Suspended sediment concentration and yield in snowmelt flood events in a small lowland river. Annals of Warsaw University of Life Sciences - SGGW, Land Reclamation 42 (1): 61-68.

HEJDUK L., BANASIK K. 2010b: Variation in suspended sediment grain sizes in a flood events in a small lowland river. IAHS Publication 337: 189-196.

HEJDUK L., BANASIK K., HEJDUK A. 2010: Monitoring ilości i jakości wody w małej zlewni [Monitoring of water quantity and quality for small catchment]. Monografie Komitetu Inżynierii Środowiska PAN 68 (1): 401-411 [Engl. summ.].

HEJDUK L., DEELSTRA J. 2011: A comparison of monitoring methods to quantify runoff and nutrient losses in Poland and Norway, Prediction and reduction of diffuse pollution, solid emission and extreme flows from rural areas - case study of small agricultural catchment (Eds K. Banasik, L. Øygarden, L. Hejduk). Wydawnictwo SGGW, Warszawa: 91-110.

JANASZ J. 2000: Warunki termiczne i śnieżne zim w Lublinie (1960/61-1994/95) [Thermic and snow conditions of winters in Lublin (1960/61-1994/95)]. Acta Agrophysica 34: 71-78 [Engl. summ.].

JANISZEWSKI F. 1988: Wskazówki dla posterunków meteorologicznych. [Tips for meteorological stations]. Wydanie II uaktualnione. IMGW, Warszawa: 242.

KOŻUCHOWSKI K., ŻMUDZKA E. 2001: Ocieplenie w Polsce. Skala i rozkład sezonowy zmian temperatury powietrza $\mathrm{w}$ drugiej połowie XX w. [The warming in Poland: The range and seasonality of the changes in air temperatue in the second half of the 20th century]. Przegląd Geofizyczny - XLVI, (1-2): 81-90 [Engl. summ.].

KUNDZEWICZ Z. 2008: Konsekwencje globalnych zmian klimatu [Impacts of global climate change]. Nauka 1: 103-118 [Engl. summ.].

KUNDZEWICZ Z. 2011: Zmiany klimatu, ich przyczyny i skutki - obserwacje i projekcje [Climate changes, their reasons and effects - observations and projections]. Landform. Analysis 15: 39-49 [Engl. summ.].

KUNDZEWICZ Z., KOZYRA J. 2011: Ograniczenie wpływu zagrożeń klimatycznych $\mathrm{w}$ odniesieniu do rolnictwa i obszarów wiejskich [Reducing impacts of climatic threats to agriculture and rural areas]. Polish Journal of Agronomy 7: 68-81 [Engl. summ.]. 
MAJEWSKI G., GOŁASZEWSKI D., PRZEWOŹNICZUK W., ROZBICKI T. 2011: Warunki termiczne i śnieżne zim w Warszawie w latach 1978/79-2009/10 [Thermal and snow conditions of winters in Warsaw 1978/79-2009/10]. Prace i Studia Geograficzne 47: 147-155 [Engl. summ.].

MAKKU P., SIRKKA T., JARI K., JARMO L. 2007: Influence of seasonal and annual hydrological variations on erosion and phosphorus transport from arable areas in Finland. Soil \& Tillage Research 93: 44-55.

MARSZ A.A. 2005: O przyczynach „wcześniejszego występowania zimy" na obszarze Europy nadbałtyckiej w ostatnim 30-leciu XX wie$\mathrm{ku}$ [The causes of the ,earlier occurrence of winter" in Baltic Europe during the last thirty years of the 20th century]. Przegląd Geograficzny 77 (3): 289-310 [Engl. summ.].

NOWOSAD M., BARTOSZEK K. 2007: Wieloletnia zmienność grubości pokrywy śnieżnej w okolicach Lublina [Long-term variability of snow cover depth in Lublin and the surrounding region]. In K. Piotrowicz, R. Twardosz [Eds]: Wahania klimatu $\mathrm{w}$ różnych skalach czasowych i przestrzennych [Climate fluctuations at different spatial and temporal scales]. Instytut Geografii i Gospodarki Przestrzennej UJ w Krakowie: 411-421 [Engl. summ.].

OLBA-ZIĘTY E., GRABOWSKI J. 2007: Warunki termiczne i śnieżne zim doliny Biebrzy w latach 1980/1981-2004/2005 [Thermal and snowy condition of winters in Biebrza valley during 1980/1981-2004/2005]. Acta Agrophysica 10 (3): 625-634 [Engl. summ.].

PACZOS S. 1982: Stosunki termiczne i śnieżne zim w Polsce [Thermal and snowy relations of winters in Poland]. Rozprawa habilitacyjna. UMCS, Lublin.

PACZOS S. 1985: Zagadnienia klasyfikacji zim w świetle różnych kryteriów termicznych [Classification of winters in the light of various thermic criteria]. Annales UMCS 40, 7: 133-155 [Engl. summ.].

PIĘTKA I. 2009: Wieloletnia zmienność wiosennego odpływu rzek polskich [Long-term variations of spring runoff of Polish rivers]. Prace i Studia Geograficzne 43: 88-95.

PIOTROWICZ K. 2002. Warunki termiczne zim w Krakowie w latach 1792-2002 [Thermal conditions of winters in Krakow in period 1792-2002]. Folia Geographica - Series Geographica-Physica XXXIII-XXXIV: 89-104. [Engl. summ.].

WOJKOWSKI J. 2009: Zróżnicowanie przestrzenne pokrywy śnieżnej na obszarze Ojcowskiego Parku Narodowego [Spatial differentiation of the snow cover in the Ojców National Park]. Prądnik. Prace i materiały muzeum im. prof. Władysława Szafera 19: 89-108 [Engl. summ.].

WOJKOWSKI J., PARTYKA J. 2009: Warunki śnieżne w Ojcowie [Nival conditions in Ojców]. Prądnik. Prace i materiały muzeum im. prof. Władysława Szafera 19: 75-88. [Engl. summ.].

ZIERNICKA-WOJTASZEKA. 2013: Klimatyczne uwarunkowania rozwoju agroturystyki $\mathrm{w}$ okresie zimowym na obszarze Polski nizinnej [Climatic conditions for the development of agrotourism during winter months in the lowland areas of Poland]. Annales Universitatis Mariae Curie-Skłodowska, Lublin - Polonia LXVIII (3), SECTIO E: 29-41 [Engl. summ.].

Streszczenie: Warunki termiczne $i$ śnieżne zim oraz wezbrania zimowe na przykladzie zlewni rzeki Zagożdżonki. Wykorzystując wskaźniki ostrości termicznej i śnieżności zim według Paczosa, przedstawiono warunki termiczne i śnieżne zim na obszarze nizinnej zlewni rzeki Zagożdżonki oraz scharakteryzowano wezbrania zimowe, odnotowane $\mathrm{w}$ badanym okresie. Podstawowe dane meteorologiczne i hydrologiczne, takie jak temperatura powietrza (maksymalna, minimalna i średnia), grubość pokrywy śnieżnej, wysokość opadów, stany wody oraz zmącenie wody w okresach zimowych lat hydrologicznych 2002-2013, pochodziły ze stacji pomiarowej SGGW zlokalizowanej w miejscowości Czarna, na obszarze badanej zlewni. W badanym okresie na obszarze zlewni Zagożdżonki dominowały zimy umiarkowanie chłodne i niezwykle małośnieżne. Niemal w każdym roku obserwowano wezbrania, których bezpośrednią przyczyną było topnienie śniegu. Wyjątek stanowił rok hydrologiczny 2008, kiedy zima była łagodna i ekstremalnie małośnieżna. Istnieje korelacja pomiędzy wskaźnikiem ostrości zimy a wskaźnikiem śnieżności. 
Istnieje również zależność pomiędzy wskaźnikiem śnieżności a przepływem maksymalnym w okresie zimowym.

Słowa kluczowe: ostrość termiczna zim, śnieżność zim, wezbrania zimowe

MS. received in February 2014

Author's addresses:

Agnieszka Hejduk

Szkoła Główna Gospodarstwa Wiejskiego

Laboratorium - Centrum Wodne

ul. Ciszewskiego 6

02-776 Warszawa, Poland

e-mail: agnieszka_hejduk@sggw.pl

Leszek Hejduk

Szkoła Główna Gospodarstwa Wiejskiego

Wydział Budownictwa i Inżynierii Środowiska

Katedra Inżynierii Wodnej

ul. Nowoursynowska 166

02-787 Warszawa, Poland

e-mail: leszek_hejduk@sggw.pl 